\title{
Penerapan Model Pembelajaran Problem Based Learning (PBL) untuk Meningkatakan Hasil Belajar IPS Siswa Kelas III SD Negeri Ciputih 01
}

\section{Cucu Nuraeni}

SD Negeri Ciputih 01

cucunuraeni539@gmail.com

\section{Article History}

received $3 / 12 / 2020$

\begin{abstract}
The purpose of this study is to improve student learning outcomes in social studies subjects in class III by applying the Problem Based Learning (PBL) learning model with the help of image media. The research that was conducted was Classroom Action Research (CAR) which was carried out in two cycles of action, each cycle consisting of two meetings. The stages for each cycle are planning, implementation, observation and reflection. Data was collected using test and non-test techniques. The results of the first cycle of research showed that $60 \%$ of students who completed the post-test were completed. In the implementation of the second cycle of students who completed after carrying out the post test was 95\%. These results indicate that the application of the Problem Based Learning (PBL) learning model with the help of image media can improve student learning outcomes in Social Sciences Class III subjects at SD Negeri Ciputih 01.
\end{abstract}

Keywords: learning outcomes, PBL, IPS

\begin{abstract}
Abstrak
Tujuan penelitian ini adalah untuk meningkatkan hasil belajar peserta didik pada mata pelajaran IPS di kelas III dengan menerapkan model pembelajaran Problem Based Learning (PBL) berbantuan media gambar. Penelitian yang dilakukan adalah jenis Penelitian Tindakan Kelas (PTK) yang dilaksanakan sebanyak dua siklus tindakan, setiap siklus terdiri dari dua pertemuan. Tahapan untuk setiap siklusnya yaitu perencanaan, pelaksanaan, pengamatan dan refleksi. Pengumpulan data dilakukan menggunakan teknik tes dan non tes. Hasil penelitian siklus I menunjukkan peserta didik yang tuntas setelah melaksanakan post tes adalah sebesar $60 \%$. Pada pelaksanaan siklus II siswa yang tuntas setelah melaksanakan post tes adalah sebesar 95\%. Hasil ini menunjukan bahwa penerapan model pembelajaran Problem Based Learning (PBL) berbantuan media gambar dapat meningkatkan hasil belajar peserta didik pada mata pelajaran IPS Kelas III di SD Negeri Ciputih 01.
\end{abstract}

Kata kunci: hasil belajar, PBL, IPS

Social, Humanities, and Education Studies (SHEs): Conference Series https://jurnal.uns.ac.id/shes

p-ISSN 2620-9284 e-ISSN 2620-9292 


\section{PENDAHULUAN}

Pada era globalisasi seperti sekarang ini, diperlukan peningkatan mutu pendidikan yang harus dilakukan secara menyeluruh meliputi aspek pengetahuan, keterampilan, sikap, dan nilai-nilai. Dewi dalam Suami (2017) menyatakan bahwa kualitas pendidikan merupakan salah satu faktor yang menentukan kualitas Sumber Daya Manusia (SDM) suatu bangsa. Terwujudnya kualitas pendidikan yang baik terjadi jika proses pembelajaran dapat berlangsung secara efektif, artinya proses pembelajaran dapat berjalan terarah dan sesuai dengan tujuan pembelajaran yang telah ditetapkan dalam kurikulum pendidikan. Kualitas pembelajaran yang baik tentu akan menghasilkan hasil belajar yang baik pula.

Dalam sistem pembelajaran saat ini guru di sekolah tidak hanya berperan sebagai penyampai materi pelajaran (transfer of knowledge), namun juga harus mampu memerankan dirinya sebagai petugas sosial, pelajar dan ilmuwan, orang tua, pencari teladan, dan pencari keamanan. Untuk menjalankan peran-peran tersebut maka guru selayaknya menempatkan dirinya sebagai seorang pendidik professional (Aeni, 2015). Guru professional harus memiliki berbagai kompetensi atau keterampilan salah satunya adalah dalam menentukan model pembelajaran yang sesuai dengan materi pelajaran.

IPS adalah salah satu mata pelajaran yang menuntut penerapan model pembelajaran yang sesuai dalam penyampaian materinya. Menurut Trianto (2010) IPS merupakan integrasi dari berbagai cabang ilmu-ilmu sosial, seperti sosiologi, sejarah, geografi ekonomi, politik, hukum dan budaya. Berdasarkan pengertian dan tujuan pembelajaran IPS tersebut, diperlukan tenaga guru yang profesional artinya mampu melakukan proses pembelajaran yang tepat dan terencana untuk mencapai hasil belajar siswa. Secara umum tujuan diberikannya pelajaran IPS disekolah adalah untuk mendidik dan memberi bekal kemampuan dasar kepada siswa untuk mengembangkan diri sesuai dengan bakat, minat, kemampuan di lingkungannya, serta memberi bekal siswa untuk melanjutkan pendidikan kejenjang yang lebih tinggi (Trianto dalam Wardani, 2018)

Penerapan model pembelajaran harus sesuai dengan karakteristik materi yang disampaikan, pemilihan model yang tidak tepat akan mengakibatkan peserta didik sulit dalam memahami materi sehingga tujuan dari pembelajaran akan sulit untuk tercapai. Hasil belajar peserta didik akan rendah jika peserta didik tidak memahami konsep materi pelajaran yang disampaikan. Rendahnya pemahaman peserta didik terhadap materi IPS masih banyak di jumpai dalam pelaksanaan pembelajaran di sekolah. Hal tersebut juga ditemui di SD Negeri Ciputih 01. Data yang diperoleh menunjukkan rendahnya hasil belajar siswa pada mata pelajaran IPS materi jenis-jenis pekerjaan. Dari 20 orang siswa hanya 3 orang yang tuntas memperoleh nilai di atas KKM dengan persentase 15\%. Rendahnya hasil belajar didominasi oleh kemampuan kinerja guru dan aktivitas siswa selama pembelajaran. Guru belum memaksimalkan pembelajaran dengan mengaitkan model sehingga proses pembelajaran berpusat pada guru (teacher centre). Ketuntasan belajar klasikal belum tercapai, yaitu sebesar $85 \%$ peserta didik memperoleh nilai di atas KKM. Hasil tersebut tentu tidak sesuai dengan harapan keberhasilan pembelajaran.

Hasil belajar siswa adalah perubahan tingkah laku, tingkah laku sebagai hasil belajar dalam pengertian yang luas mencakup bidang kognitif, afektif, psikomotoris (Sudjana, 2011). Sedangkan menurut Rusmono (2012) hasil belajar merupakan perubahan prilaku individu yang meliputi ranah kognitif, afektif, dan psikomotorik. Hasil belajar merupakan hasil dari suatu interaksi tindakan belajar dan tindakan mengajar. Dari sisi guru, tindak mengajar diakhiri dengan proses evaluasi hasil belajar, sedangkan dari sisi siswa, hasil belajar merupakan berakhirnya pengalaman dari puncak proses belajar (Dimyati dalam Wardani, 2018). Hasil belajar yang dimaksud dalam penelitian ini adalah hasil belajar siswa pada mata pelajaran IPS setelah 
mengikuti proses pembelajaran dengan menerapkan model Problem Based Learning (PBL). Dalam penelitian ini, pembelajaran dikatakan tuntas apabila $85 \%$ siswa mendapat nilai $\geq 70$ berdasarkan KKM yang telah ditentukan sekolah.

Ruang lingkup mata pelajaran IPS adalah hal-hal yang berkenaan dengan manusia dan kehidupannya meliputi semua aspek kehidupan manusia sebagai anggota masyarakat. Maka dalam penelitian ini akan menggunakan model pembelajaran PBL. Model Pembelajaran PBL ini didukung dengan teori belajar konstruktivisme dengan ciri pemahaman diperoleh dari hasil interaksi dengan skenario/kegiatan yang berkaitan dengan permasalahan dan lingkungan belajar, proses pembelajaran didasarkan pada masalah dan proses inquiry masalah dengan menciptakan disonansi kognitif yang menstimulasi belajar serta adanya proses kolaborasi dan evaluasi terhadap keberadaan sebuah sudut pandang (Rusman, 2013). Menurut Warsono (dalam Wardani, 2018) berdasarkan pendapat Arends, pada esensinya pembelajaran berbasis masalah (Problem Based Learning) adalah model pembelajaran yang berlandaskan kontruktivisme dan mengakomodasikan keterlibatan siswa dalam belajar serta terlibat dalam pemecahan masalah yang kontekstual didasarkan pada banyaknya permasalahan yang membutuhkan penyelidikan autentik yakni penyelidikan yang membutuhkan penyelesaian nyata dari permasalahan yang nyata.

Menurut Wena dalam Surya (2017) mengemukakan bahwa model PBL merupakan strategi pembelajaran dengan menghadapkan peserta didik pada permasalahan-permasalahan praktis sebagai pijakan dalam belajar atau dengan kata lain peserta didik belajar melalui permasalahan. Problem based learning adalah model pembelajaran yang bercirikan adanya permasalahan nyata sebagai konteks untuk siswa belajar berpikir dan terampil dalam memecahkan masalah (Nopia, 2016). Model pembelajaran Problem Based Learning (Belajar Berbasis Masalah) diterapkan untuk merangsang berpikir tingkat tinggi siswa dalam situasi berorientasi masalah, termasuk di dalamnya belajar bagaimana belajar. Model ini melatih siswa untuk memecahkan masalah dengan pengetahuan yang dimilikinya. Proses tersebut akan membuat terbangunnya pengetahuan baru yang lebih bermakna bagisi swa (Gunantara, 2014).

Berdasarkan pendapat ahli di atas, dapat disimpulkan bahwa model PBL adalah suatu model pembelajaran yang menggunakan masalah dunia nyata sebagai langkah awal bagi peserta didik untuk belajar dalam mendapatkan pengetahuan dan konsep yang esensi dari setiap materi pembelajaran yang telah dimiliki peserta didik sebelumnya, sehingga terbentuklah pengetahuan yang baru (Surya, 2017).

Menurut Ibrahim dalam Wardani (2018) langkah PBL meliputi Orientasi siswa pada masalah, mengorganisasi siswa untuk belajar, membimbing pengalaman individual/kelompok, mengembangkan dan menyajikan hasil karya serta menganalisis dan mengevaluasi proses pemecahan masalah.

Berdasarkan uraian di atas dalam upaya meningkatkan hasil belajar IPS materi jenis-jenis pekerjaan pada siswa kelas III SD Negeri Ciputih 01, maka peneliti akan menerapkan model pembelajaran PBL. Rumusan masalah dalam penelitian ini adalah apakah dengan menerapkan model PBL dapat meningkatkan hasil belajar IPS siswa. Beberapa penelitian tentang penggunaan model PBL menjadi referensi dalam penelitian ini, salah satunya adalah penelitian yang dilakukan oleh Wardani (2018) Hasil penelitiannya menunjukkan bahwa hasil belajar siswa meningkat dengan menggunakan model PBL pada mata pelajaran IPS.

\section{METODE}

Jenis penelitian ini adalah Penelitian Tindakan Kelas (Classroom Action Research) dengan menggunakan model pembelajaran PBL. Menurut Wardhani (2010) bahwa langkah-langkah Penelitian Tindakan Kelas (PTK) terdiri dari empat tahap, yaitu 
merencanakan (planning), melakukan tindakan (acting), mengamati (observing), dan melakukan refleksi (reflecting). Analisis penelitian ini adalah analisis deskriptif kuantitatif kualitatif dimana dalam penelitian ini selain penyajian hasil berupa data maupun angka peneliti juga menentukan bagaimana cara pengolahan hasil penelitian yakni dengan membuat analisisnya penggunaan model PBL dengan membandingkan hasil setiap siklus pelaksanaan. Penelitian ini dilaksanakan pada peserta didik kelas III SD Negeri Ciputih 01 tahun Pelajaran 2018/2019 dalam dua siklus pembelajaran dengan dua pertemuan disetiap siklusnya. Siklus I dilaksanakan pada tanggal 5 dan 12 Maret 2019. Siklus II dilaksanakan pada tanggal 19 dan 26 Maret 2019. Teknik pengumpulan data yang dilakukan dengan observasi dan tes. Observasi meliputi observasi penerapan metode eksperimen dalam pembelajaran, aktivitas dan keterampilan peserta didik serta aktivitas guru. Untuk mengetahui hasil belajar dengan menggunakan tes tulis dengan soal berbentuk pilihan ganda.

\section{HASIL DAN PEMBAHASAN}

Pelaksanaan tindakan pembelajaran siklus I merupakan usaha perbaikan pembelajaran dari hasil sebelumnya. Pelaksanaan pembelajaran siklus I dilaksanakan dengan dua kali pertemuan dengan empat tahapan yakni perencanaan, tindakan, observasi dan refleksi. Pada tahap perencanaan peneliti menyusun berbagai perangkat pembelajaran yang akan digunakan dalam proses pembelajaran. Pada tahap pelaksanaan tindakan peneliti menerapkan model pembelajaran PBL dalam menyampaikan materi IPS tentang jenis-jenis pekerjaan. Penerapan model PBL ini dilaksanakan dengan mengacu pada sintak atau tahapan-tahapan pelaksanaan PBL, yaitu memberikan orientasi masalah terhadap siswa, dalam hal ini adalah masalah yang terkait dengan berbagai jenis pekerjaan. Selanjutnya adalah mengorganisasikan siswa untuk belajar dengan membentuk siswa menjadi kelompok-kelompok diskusi. Langkah beriktunya adalah membimbing siswa dalam penyelidikan kelompok untuk menemukan pemecahan masalah yang telah disajikan, kemudian mengembangkan dan menyajikan hasil karya serta tahap akhir adalah menganalisis dan mengevaluasi. Untuk mengetahui penguasaan maupun hasil belajar siswa maka tes evaluasi dilaksanakan pada akhir pembelajaran siklus I pertemuan kedua. Data hasil tes peserta didik pada siklus I pembelajaran IPS materi jenis-jenis pekerjaan dapat dilihat pada tabel di bawah ini.

Tabel 1. Hasil Belajar IPS Peserta Didik Siklus I

\begin{tabular}{|c|c|c|c|c|}
\hline \multirow[t]{2}{*}{ Pembelajaran } & \multicolumn{2}{|c|}{ Peserta Didik Tuntas } & \multicolumn{2}{|c|}{$\begin{array}{c}\text { Peserta Didik Belum } \\
\text { Tuntas }\end{array}$} \\
\hline & Jml & $\%$ & Jml & $\%$ \\
\hline Siklus I & 12 & 60 & 8 & 40 \\
\hline
\end{tabular}

Berdasarkan tabel di atas dapat kita ketahui bahwa pada pembelajaran IPS Siklus I dengan menerapkan model pembelajaran Problem Based Learning (PBL) dengan berbantuan media gambar, dengan KKM IPS 70 peserta didik yang tuntas mencapai nilai KKM adalah sebanyak 12 peserta didik dengan persentase ketuntasan $63,6 \%$, sedangkan peserta didik yang belum tuntas adalah sebanyak 8 peserta didik atau $40 \%$. Meskipun pada pembelajaran siklus I terjadi peningkatan hasil belajar dari pembelajaran awal (pra siklus) namun hasil pembelajaran Siklus I ini belum mencapai ketuntasan klasikal yang diharapkan yaitu $80 \%$ dari jumlah peserta didik telah mencapai nilai KKM.

Masih belum tercapainya ketuntasan klasikal dikarenakan pada pelaksanaan siklus I masih banyak siswa yang belum aktif dalam proses pembelajaran, karena pembagian kelompok yang terlalu besar. Berdasarkan refleksi hasil pembelajaran pada 
pembelajaran siklus I maka tindakan akan dilanjutkan dengan siklus II. Pada pembelajaran siklus II membahas kembali materi tentang jenis-jenis pekerjaan dengan pembagian kelompok lebih kecil serta ditambah dengan bantuan media gambar. Seperti halnya pada pelaksanaan pembelajaran siklus I, pelaksanaan model pembelajaran PBL dengan mengacu pada sintaks atau tahap pelaksanaan seperti pada pembelajaran siklus I. Adapun hasil test evaluasi peserta didik pada pembelajaran siklus II mata pelajaran IPS materi jenis-jenis pekerjaan pada siswa kelas III SD Negeri Ciputih 02 dapat dilihat pada tabel berikut.

Tabel 2. Hasil Belajar IPS Peserta Didik Siklus II

\begin{tabular}{ccccc}
\hline \multirow{2}{*}{ Pembelajaran } & \multicolumn{3}{c}{ Peserta Didik Tuntas } & \multicolumn{2}{c}{$\begin{array}{c}\text { Peserta Didik Belum } \\
\text { Tuntas }\end{array}$} \\
\cline { 2 - 5 } & Jml & $\%$ & Jml & $\%$ \\
\hline Siklus II & 19 & 95 & 1 & 5 \\
\hline
\end{tabular}

Berdasarkan tabel di atas dapat kita ketahui bahwa pada pembelajaran IPS materi jenis-jenis pekerjaan siklus II dengan menerapkan model pembelajaran Problem Based Learning (PBL) yang dibantu dengan media gambar, peserta didik yang tuntas mencapai nilai KKM adalah sebanyak 19 peserta didik dengan persentase ketuntasan mencapai $95 \%$. Sedangkan peserta didik yang belum tuntas hanya 1 peserta didik atau $5 \%$ Dari hasil pembelajaran siklus II persentase ketuntasan peserta didik telah mencapai $95 \%$ artinya telah mencapai ketuntasan klasikal yang diharapkan yaitu $85 \%$, maka pembelajaran dihentikan pada siklus II. Aktivitas siswa pada pembelajaran siklus II lebih baik dibandingkan siklus I. Pelaksanaan diskusi berjalan dengan efisien.

Tingkat ketuntasan belajar peserta didik melalui penerapan model pembelajaran PBL diketahui dengan menganalisis hasil tes evaluasi yang diberikan kepada peserta didik setelah menerapkan model PBL. Berdasarkan hasil penelitian dari dua siklus pembelajaran di atas dapat kita ketahui adanya peningkatan persentase ketuntasan belajar siswa pada mata pelajaran IPS materi jenis-jenis pekerjaan dengan menerapkan model pembelajaran Problem Based Learning (PBL) dari siklus I ke siklus II. Data peningkatan persentae ketuntasan belajar peserta didik dapat dilihat pada tabel di bawah ini.

Tabel 3. Rekapitulasi Ketuntasan Belajar Siklus I dan Siklus II

\begin{tabular}{lcccccc}
\hline Pembelajaran & $\begin{array}{c}\text { Jumla } \\
\mathbf{h}\end{array}$ & \multicolumn{2}{c}{ Siswa Tuntas } & \multicolumn{2}{c}{$\begin{array}{c}\text { Siswa belum } \\
\text { Tuntas }\end{array}$} & \multirow{2}{*}{$\begin{array}{c}\text { Peningkatan } \\
\%\end{array}$} \\
\cline { 3 - 6 } & Siswa & Jml & $\%$ & Jml & $\%$ & Ketuntasan \\
\hline Siklus I & 20 & 12 & 60 & 8 & 40 & \\
Siklus II & 20 & 19 & 95 & 1 & 5 & 35 \\
\hline
\end{tabular}

Berdasarkan tabel rekapitulai di atas dapat kita ketahui bahwa pada pembelajaran siklus I dari 20 siswa yang mengikuti pembelajaran jumlah siswa yang tuntas adalah sebanyak 12 siswa dengan persentase ketuntasan $60 \%$. Peserta didik yang belum tuntas adalah 8 peserta didik atau sebesar $40 \%$. Pada pembelajaran siklus II, peserta didik yang tuntas adalah sebanyak 19 siswa dengan persentase ketuntasan sebesar $90 \%$. Peserta didik yang belum tuntas hanya 1 peserta didik atau $5 \%$. Dari hasil tersebut terjadi peningkatan persentase ketuntasan belajar peserta didik dari siklus I ke siklus II sebesar 35\%.

Berdasarkan data yang terkumpul dan hasil analisis yang diperoleh dari hasil tes evaluasi menunjukkan adanya peningkatan hasil belajar siswa dengan menerapkan model PBL. Ketuntasan klasikal belajar siswa telah mencapai 95\%. Peningkatan yang 
terjadi dari siklus I ke siklus II yaitu 35\%. Mengacu pada teori belajar tuntas yang dikemukakan Mulyasa dalam Nurhaliza (2018) bahwa seorang peserta didik dipandang tuntas belajar jika ia mampu menyelesaikan, menguasai kompetensi atau mencapai tujuan pembelajaran minimal $70 \%$ dari seluruh tujuan pembelajaran. Sedangkan keberhasilan kelas dapat dilihat dari jumlah peserta didik yang mampu menyelesaikan atau mencapai sekurang-kurangnya $80 \%$ dari jumlah peserta didik yang ada dikelas tersebut. Dengan demikian maka penerapan model PBL dapat meningkatkan hasil belajar siswa pada mata pelajaran IPS.

Berdasarkan hasil pembelajaran tersebut maka penggunaan model pembelajaran PBL sudah tuntas, karena secara keseluruhan dari jumlah siswa sudah mampu menyelesaikan soal-soal, mencapai indikator dan tujuan pembelajaran pada materi jenis-jenis pekerjaan. Hasil ini juga relevan degan penelitian yang dilakukan Wardani (2018). Hasil penelitian tersebut menunjukkan bahwa penggunaan model PBL sangat berpengaruh untuk peningkatan hasil belajar siswa pada materi keragaman sosial budaya berdasarkan penampakan alam.

Pemilihan model pembelajaran yang tepat akan mempengaruhi hasil belajar hasil peserta didik, dalam penelitian ini pemilihan model PBL telah berhasil meningkatkan hasil belajar siswa pada mata pelajaran IPS materi jenis-jenis pekerjaan. Hal ini sejalan dengan pernyataan dari Syah (2011) bahwa salah satu faktor yang mempengaruhi hasil belajar adalah faktor strategi belajar. Faktor yang mempengaruhi dalam penelitian ini adalah faktor pendekatan karena faktor pendekatan disini yaitu menggunakan model Problem Based Learning.

Berdasarkan hasil penelitian dan pembahasan di atas maka dapat disimpulkan bahwa Model pembelajaran PBL dapat meningkatkan hasil belajar siswa pada mata pelajaran IPS khususnya pada materi jenis-jenis pekerjaan.

\section{SIMPULAN}

Penerapan model pembelajaran Problem Based Learning (PBL) pada proses pembelajaran dapat meningkatkan hasil belajar IPS peserta didik kelas III SD Negeri Ciputih 01 materi jenis-jenis pekerjaan. Hal ini ditunjukkan dengan adanya peningkatan persentase ketuntasan belajar dimana pada siklus I persentase ketuntasan adalah $60 \%$ sedangkan pada siklus II persentase ketuntasan menjadi 95\%. Peningkatan hasil belajar terjadi karena adanya kesan pembelajaran yang mendalam dari peserta didik tehadap materi yang diajarkan melalui belajar berbasis masalah. Peserta didik dapat menemukan sendiri pemecahan sebuah permasalahan yang ada dalam materi pembelajaran. Berdasarkan hasil penelitian yang telah dilaksanakan maka model PBL merupakan salah satu model pembelajaran yang harus dikuasai penerapannya oleh guru, dan merupakan salah satu model yang cocok digunakan dalam pembelajaran IPS di kelas III sekolah dasar. Dari hasil penelitian di atas peneliti mengajukan saran sebagai berikut: (1) sebaiknya guru harus merancang mempersiapkan dengan cermat sebuah proses pembelajaran agar tujuan pembelajaran dapat tercapai, (2) guru harus dapat memilih dan menentukan model pembelajaran yang tepat yang sesuai dengan karakteristik materi pelajaran (3) bagi peneliti yang akan melakukan penelitian dengan meggunakan model PBL, penelitian ini dapat dijadikan sebagai acuan atau referensi untuk membantu dalam melakukan penelitian.

\section{DAFTAR PUSTAKA}

Aeni, A. (2015). Menjadi Guru SD Yang Memiliki Kompetensi Personal-Religius Melalui Program One Day One Juz (ODOJ). Mimbar Sekolah Dasar, 2(2), 212-223.

Gunantara, Gd. Md Suarjana, Pt. Nanci Riastini. (2014). Penerapan Model Pembelajaran Problem Based Learning Untuk Meningkatkan Kemampuan Pemecahan Masalah Matematika Siswa Kelas V. Jurnal Mimbar PGSD Universitas Pendidikan Ganesha Jurusan PGSD Vol: 2 No: 1 
Nopia,R., Julia, \& Sujana, A. (2016). Pengaruh Model Problem Based Learning Terhadap Keterampilan Berpikir Kritis Siswa Sekolah Dasar Pada Materi Daur Air. Pena IImiah,1(1), 641-650.

Rusman. (2013). Belajar dan Pembelajaran Berbasis Komputer. Bandung: Alfabet.

Suami, D.A.K.. (2017). Penerapan Model Pembelajaran Problem Based Learning Untuk Meningkatkan Prestasi Belajar IPS. Jurnal IImiah Sekolah Dasar. Vol 1 (3) pp. 206-214.

Sudjana, N. (2011). Penilaian Hasil Proses Belajar Mengajar, (cetakan ke-16). Bandung: Remaja Rosdakarya.

Surya, Y.F. (2017). Penerapan Model Pembelajaran Problem Based Learning Untuk Meningkatkan Hasil Belajar Matematika Siswa Kelas IV SDN 016 Langgini Kabupaten Kampar. Cendikia: Jurnal Pendidikan Matematika, 1(1).38-53

Syah, M. (2011). Psikologi Pendidikan Dengan Pendekatan Baru, (Cetakan ke-17). Bandung: PT Remaja Rosdakarya.

Trianto. (2010). Mendesain Model Pembelajaran Inovatif-Progresif Konsep, Landasan Dan Implementasinya Pada Kurikulum Tingkat Satuan Pendidikan (KTSP). Jakarta: Kencana.

Wardani, W.F.. (2018). Penerapan Model Problem Based Learning (PBL) Untuk Meningkatkan Hasil Belajar Siswa Pada Mata Pelajaran IPS Kelas IV MI Islamiyah Sumberrejo Batanghari Tahun Pelajaran 2017/2018. Skripsi. IAIN Metro

Wardhani, I.G.A.K. (2010). Penelitian Tindakan Kelas (Cetakan Kesepuluh). Jakarta: Universitas Terbuka. 